\title{
Management and Treatment of Human Lice
}

\author{
Abdoul Karim Sangaré, ${ }^{1,2}$ Ogobara K. Doumbo, ${ }^{2}$ and Didier Raoult ${ }^{1}$ \\ ${ }^{1}$ Research Unit on Emerging Infectious and Tropical Diseases (URMITE), UMR CNRS 7278, IRD 198, INSERM 1095, \\ Faculty of Medicine, Aix-Marseille University, 27 boulevard Jean Moulin, 13005 Marseille, France \\ ${ }^{2}$ Epidemiology Department of Parasitic Diseases, Faculty of Medicine and Odonto-Stomatology, \\ Faculty of Pharmacy (MRTC/DEAP/FMOS-FAPH) UMI3189, University of Sciences, Techniques and \\ Technologies of Bamako (USTTB), Bamako, Mali
}

Correspondence should be addressed to Didier Raoult; didier.raoult@gmail.com

Received 11 January 2016; Revised 17 April 2016; Accepted 16 June 2016

Academic Editor: Patricia Salgueiro

Copyright (C) 2016 Abdoul Karim Sangaré et al. This is an open access article distributed under the Creative Commons Attribution License, which permits unrestricted use, distribution, and reproduction in any medium, provided the original work is properly cited.

Of the three lice (head, body, and pubic louse) that infest humans, the body louse is the species involved in epidemics of louseborne typhus, trench fever, and relapsing fever, but all the three cause pediculosis. Their infestations occur today in many countries despite great efforts to maintain high standards of public health. In this review, literature searches were performed through PubMed, Medline, Google Scholar, and EBSCOhost, with key search words of "Pediculus humanus", "lice infestation", "pediculosis", and "treatment"; and controlled clinical trials were viewed with great interest. Removing lice by hand or with a lice comb, heating infested clothing, and shaving the scalp were some of the oldest methods of controlling human lice. Despite the introduction of other resources including cresol, naphthalene, sulfur, mercury, vinegar, petroleum, and insecticides, the numbers of lice infestation cases and resistance have increased. To date, viable alternative treatments to replace insecticides have been developed experimentally in vitro. Today, the development of new treatment strategies such as symbiotic treatment and synergistic treatment (antibiotics + ivermectin) in vitro has proved effective and is promising. Here, we present an overview on managing and treating human lice and highlight new strategies to more effectively fight pediculosis and prevent resistance.

\section{Lice and Their Public Health Impact}

1.1. Overview. Lice have been parasites of humans for thousands of years and differ according to their habitat on the host [1]. The three sucking lice that infest humans are the body louse (Pediculus humanus humanus), the head louse (Pediculus humanus capitis), and the pubic or "crab" louse (Pthirus pubis) [2]. Body lice and head lice harbor the same endosymbiotic microorganism that seems to be essential for the production of nutritional components such as the $\mathrm{B}$ vitamins lacking in host feedings [3,4]. In 2006, SasakiFukatsu et al. were the first to describe the phylogenetic placement of the primary endosymbiont of human body lice; they identified this endosymbiont as a $\gamma$-proteobacterium and named it Candidatus Riesia pediculicola [5].

Each year, louse infestations still affect hundreds of millions of people worldwide [6], 6 to 12 million children in the United States annually [7]. Analysis of data on the global incidence of pediculosis has shown that this remains a major health problem in many countries [8]. Thus, the head louse is prevalent in all countries, and outbreaks have been described at all levels in society [9]. However, children of primary school age constitute the largest group of people affected [10]. Approximately 6-12 million cases of infestation occur each year in the United States among children 3-12 years old [11]. Infestation may be increased in school children with more siblings and of lower socioeconomic group [12]. The pubic louse is usually a sexually transmitted organism, although atypical locations such as eyebrows and eyelashes have been reported $[9,13]$. The body louse lives in clothes and multiplies when cold, promiscuity, lack of hygiene, and war are present. Its prevalence also reflects the socioeconomic level of society [14]. During the civil wars in Burundi, Rwanda, and Zaire in the 1990s, the prevalence of lice infestations reached $90-100 \%$ [15]. The body louse is the species known to be involved in epidemics of louse-borne infectious diseases [16], but all the 
three cause pediculosis which is highly contagious and easily transmitted by close body-to-body contact or contact with infested linen, brushes, or clothes, according to the species of louse. A louse-infested person can be infested by thousands of lice, each of which bites on average five times per day for body lice [17]. In literature, several methods were used to get rid of lice infestations. Thus, this review summarizes the management methods and various strategies used in treating these hematophagous parasites.

1.2. Physiology and Exponential Multiplication of Lice. Humidity is a critical factor for lice; the optimal humidity for survival is in the range of $70-90 \%$ [9]; they cannot survive when this value falls below $40 \%$. Temperature is also highly influential on the louse's physiology. According to Maunder, laboratory lice prefer a temperature between 29 and $32^{\circ} \mathrm{C}$ [9]. At $50^{\circ} \mathrm{C}$, body lice die, and this temperature is critical when washing clothes, as water and soap alone will not kill lice [43]. Although eggs can survive at lower temperatures, their viability is limited to 16 days [43].

A louse typically feeds five times a day and each female can have several successive partners. At maturity, lice can mate every day and each female lays $8-10$ eggs per day, with a female able to lay up to 300 eggs during her lifetime. During the prolonged mating process, both the male and the female will continue to feed [9]. Eggs are laid in the folds of clothing for body lice and in the hair for head lice; they are held in place by an adhesive produced by the mother's accessory gland [13]. Hatching occurs 7-10 days after laying. There are three nymphal stages (L1, L2, and L3), moulted the third, fifth, and tenth days after hatching and which are differentiated by their size.

1.3. Remarks on the Genetics of the Louse (Body Lice versus Head Lice) and Its Symbiont. Genetic tools were used to separate human lice into head lice and body lice. The first study was based on the 18S rRNA gene [44], and subsequent studies focused on mitochondrial genes [45-47] and intergenic spacers $[48,49]$. These studies revealed that there are three clades of head lice, one of which may also be body lice (clade A) [46, 47]. Subsequently, a fourth clade including both head and body lice was detected in Congo [50]. A transcriptome study of human head and body lice revealed that there is only one gene present in body lice but not in head lice. Otherwise, the main differences identified between head lice and body lice concern gene expression levels [51]. Indeed, 14 putative differentially expressed genes were identified by comparing head louse and body louse data. However, head lice and body lice have almost the same genomic content but are phenotypically different (different ecotypes) as a result of differential gene expression [52]. Thus, a rapid multiplex realtime PCR assay was established that differentiates between head and body lice with $100 \%$ specificity and sensitivity [53]. Based on these studies, we can suggest that the clade A head louse has a deleted genome and originated from the body louse. The opposite hypothesis was considered evident for years $[9,45,54]$.

The primary endosymbiont of human body lice is a bacterium belonging to the family Enterobacteriaceae in the
$\gamma$-Proteobacteria class [5]. Organs called mycetome host the primary endosymbiont, except during passage to the ovaries for transovarial transmission [55]. A recent study of the genome of Candidatus Riesia pediculicola revealed a small genome, $574 \mathrm{kB}$, similar to what is found in other insect primary endosymbionts [56]. The reduction in genome size and the high AT-bias suggest an ancient association between the louse and its primary endosymbiont [56]. Thus, Candidatus Riesia pediculicola is an insect primary endosymbiont ( $\mathrm{P}$ endosymbiont) that has been associated with the louse for 1325 million years [52].

1.4. Louse-Borne Infectious Diseases. Louse-borne diseases are associated with a high prevalence of body louse infestation and have recently reemerged in jails and refugee camps in central and eastern Africa [15], in rural communities in the Peruvian Andes [57], in rural populations in Russia [58], and in homeless populations living in poor hygiene conditions in developed countries [59-63]. Given the phagocytic activity of their immune system, it is more likely that body lice are vectors of pathogens than head lice [64]. The physiological difference between head and body lice is that head lice do not transmit human diseases, whereas body lice are vectors of bacterial diseases transmitted to humans, including trench fever caused by Bartonella quintana, relapsing fever caused by Borrelia recurrentis, and epidemic typhus caused by Rickettsia prowazekii $[1,57,65]$. Acinetobacter baumannii was found in $21 \%$ of the 622 body lice collected worldwide [66], but the transmission of the infection $A$. baumannii by body louse has not yet been demonstrated. In Morocco in the 1940s, the causative agent of plague, Yersinia pestis, was recovered from a body louse collected from a septicemic patient $[67,68]$. In the Democratic Republic of the Congo, DNA from Yersinia pestis was observed in one head louse and two body lice [50,69]. In addition, the experimental model to evaluate the human body louse as a vector of plague has been demonstrated in our laboratory [70].

Head lice can carry pathogens although their role as a vector has not yet been clarified. DNA from B. quintana was found in head lice from Nepalese children in 2006 [71], from homeless individuals in the USA in 2009 [65], and from the local population in Congo, Madagascar, and Senegal [72]. It was also found in head louse nits from a homeless person in Marseille, France [73], and in head lice from Ethiopian [74] and Senegalese [75] patients. DNA from A. baumannii was detected in $33 \%$ and $3 \%$ of the head lice collected from schoolchildren in Paris, France [76], and Diankabou, Mali, respectively [77].

\section{Diagnosis of Lice Infestations}

Lice infestation is a common problem and diagnosis is generally based on the presence of nits or lice. The characteristic itching or pruritus that accompanies infestation may in some cases be complicated by bacterial infections (Figures 1(a) and 1(b)) that occur when the skin becomes excoriated $[78,79]$. Lice may be seen on the scalp, in the hair, or on clothing of the infected person. However, the techniques used for 


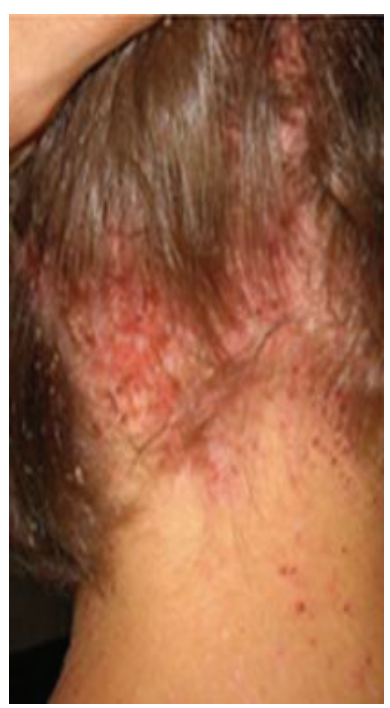

(a)

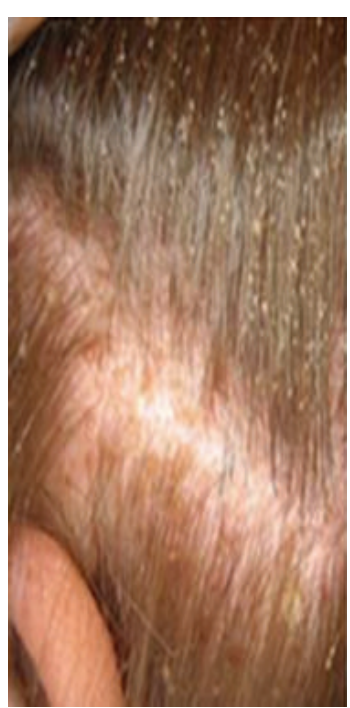

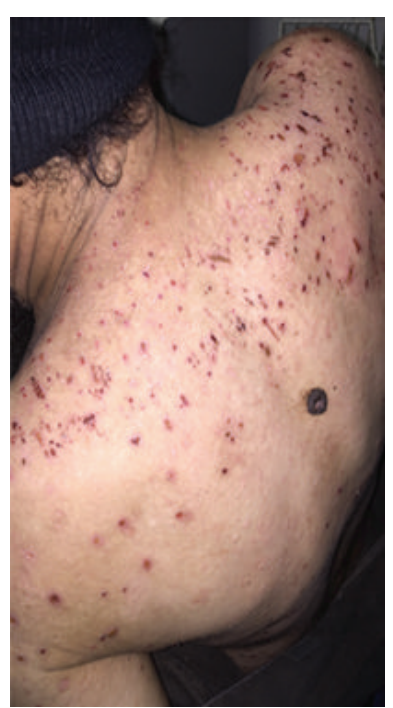

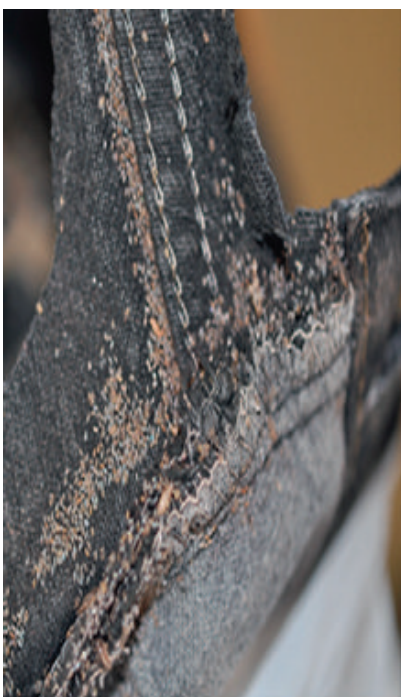

(b)

FIGURE 1: Nuisance related to lice: (a) scalp infection caused by head lice; (b) scraping lesions related to body lice infestation.

diagnosing a louse infestation (Pediculus humanus) are a source of controversy. Most epidemiological studies have used direct visual examination (visual inspection). Direct visual examination (Figure $2(\mathrm{a})$ ) with a magnifying glass and combing with louse comb (Figures 2(b) and 2(c)) are two frequently used methods; but the first is not a reliable method for diagnosing living lice on hair [80]. It underestimates active infestation and is only useful with heavily infested patients. Elsewhere, Balcioglu et al. have demonstrated in their study that plastic detection comb is better than visual screening for diagnosis of head louse infestation [81].

\section{Treatment Strategies}

The fight against pediculosis is certainly a very ancient concern and various methods have been used to get rid of it.

3.1. Historical Methods. Removing lice by hand (Figure 2(a)) or with a lice comb (Figures 2(b) and 2(c)) and shaving the scalp were some of the oldest methods of controlling human lice $[82,83]$.

3.1.1. Using Hands. This was the first means used before the comb was invented. Crushing lice with your fingers should be strongly discouraged because it can lead to bacterial penetration through the cutaneous route. Manual removal of nits (especially the ones within $1 \mathrm{~cm}$ of the scalp) can only be recommended after treatment with a product [84]. One study showed that manual removal is less effective than pediculicides and does not improve results even when used in addition to a pediculicide treatment [35].

3.1.2. Using Combs. Combs for the removal of adult lice and nits have been used since ancient times [82]. Today, many different types of combs are sold to control lice. Combing can be undertaken every 1-3 days. This method not only is for treatment but can be for prevention, to remove mature lice which might otherwise lay eggs and perpetuate the life cycle. However, it was also demonstrated that the diagnosis of louse infestation using a louse comb is four times more effective $(25 \%$ versus $6 \%)$ than direct visual examination and twice (57 seconds versus 116 seconds) as fast [80]. This study was proven by Balcioglu and colleagues in 2008 [81]. Compared to phenothrin in clinical trials, the bug busting method is effective for managing head lice infestation [41]. Thus, we can conclude that using a louse comb to screen patients for lice infestation and treating with a pediculicide are effective.

3.1.3. Shaving. Head shaving can be a simple method to remove the lice and eggs. It was noted that short hair does not prevent head lice infestations [78]. However, head shaving should be avoided whenever possible because it is humiliating, especially for girls. Complete shaving of the head generally does eliminate lice and prevents reinfestation but is rarely an appropriate measure to take in response to infestation [85].

3.1.4. Using Heat. A further step is heating infested clothing and bedding with hot water to destroy all stages of lice. The heat necessary for the destruction of both lice and nits is $52^{\circ} \mathrm{C}$ for 30 minutes [86]. This method can be easily applied to infested clothes using hot water but cannot be used on infested hair. Lice may, however, make themselves heat resistant by a hormonal process. Heat resistance is achieved by lice excreting heat resistant, protective secretion through their outer skeleton. This is part of the natural defense mechanism of lice. When the lice have become heat resistant, they can tolerate very high temperatures (above $100^{\circ} \mathrm{C}$ ) [87].

3.1.5. Chemical Products. Cresol, naphthalene, sulfur, mercury, petroleum, naphthalene, and petrolatum were 


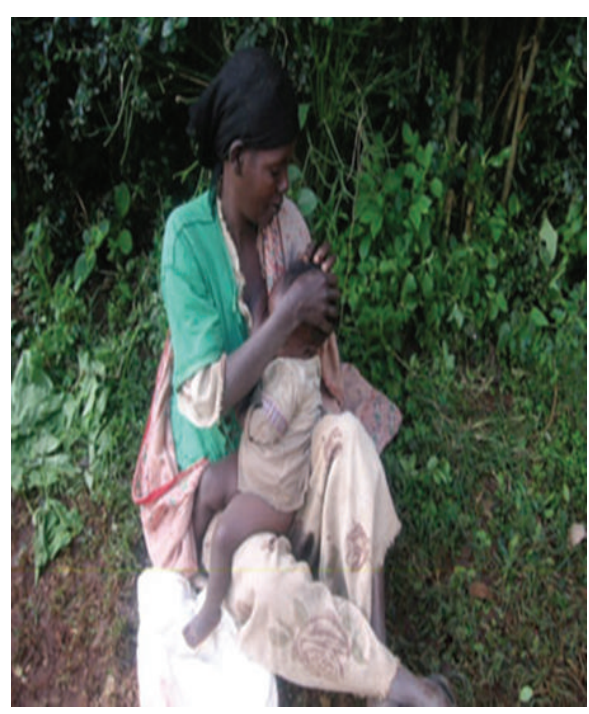

(a)

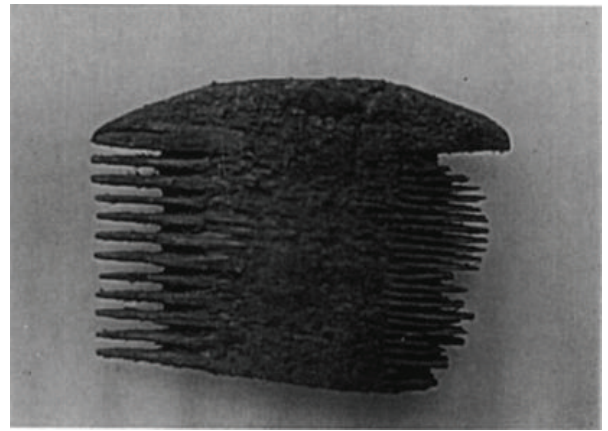

(b)

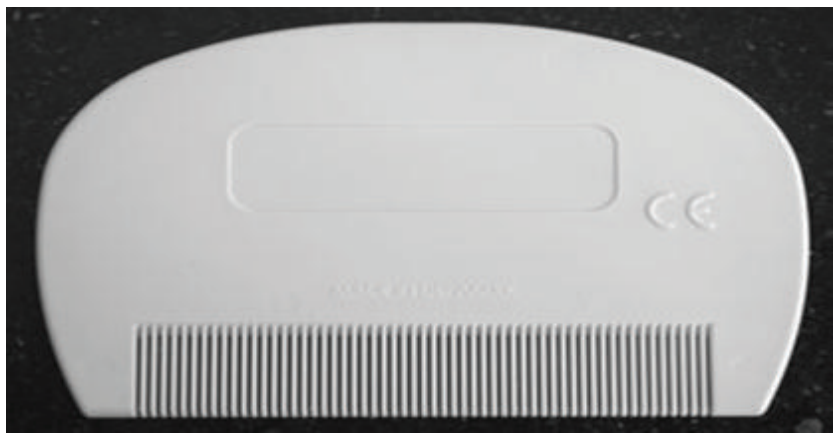

(c)

FIGURE 2: A few historical methods to get rid of lice. (a) Detecting lice or nits by direct visual examination; (b) wooden comb found at Ein Rachel (Negev Desert) (100 BC-200 AD) containing 10 head lice and 5 nits; (c) modern plastic comb.

employed alone or, for some of these products, in combination with oil or vinegar $[83,88]$. Due to major adverse effects and/or resistance, all of these methods have now been discontinued.

\subsection{Local Products}

3.2.1. Study Methods: Sensitivity and Resistance. Measurement of the susceptibility or resistance per se may be performed only by using doses of insecticide applied via an inert carrier, and this is the basis of the WHO tests and their variants [89-93]. The majority of studies have used WHOrecommended protocols [94] or modified versions of those techniques. Studies have sought to measure the effectiveness of pediculicides in controlled laboratory test systems. Measurement of sensitivity to insecticide in formulations cannot be generic and must be measured either in vivo by means of a clinical trial or in vitro/ex vivo by using the whole formulation [95]. The methodology of ex vivo tests conducted by Meinking and colleagues $[96,97]$, in which the lice were allowed to continuously bubble on wet sponge with pediculicidal and without subsequent washing, may have given unrepresentative results in some cases. Two studies evaluated resistance to permethrin using techniques on the basis of a WHO method employing single concentration applications of insecticide to filter papers and measuring time to death of the test insects, in order to record LT50 and LT95 [94]. However, in one of these studies the levels of insecticide used to measure the lethal dose were considerably lower than those recommended by WHO [98], so in some cases the measure may have been more of vigor tolerance (reduced sensitivity of an insect population due to elimination of the least robust insects by weak selection) than resistance [99]. Tests using laboratory-reared body lice may be less discriminatory than tests employing wild-caught head lice, and they do not identify variations of effectiveness likely to arise as a result of selection pressure [96]. Observations of lice that survived adequate clinical applications of insecticide products containing more than $13 \%$ of monoterpenes suggest they have already become resistant to these chemicals [95].

3.2.2. Pediculicides. Since World War II, many insecticides have been used against lice. Among those for treatment of head and body lice were organochlorines (DDT, lindane), organophosphates (malathion), carbamates (carbaryl), pyrethrins (pyrethrum), and pyrethroids (permethrin, 
TABLE 1: Main products used in clinical trials in humans: efficacy and safety.

\begin{tabular}{|c|c|c|c|}
\hline Comparison of treatments & Efficacy & Safety & References \\
\hline 1,2-Octanediol versus malathion & More effective & Adverse effects reported & {$[18]$} \\
\hline 1,2-Octanediol versus placebo & Effective & No serious adverse events & [19] \\
\hline Cocamide DEA versus permethrin & May be as effective & Adverse effects reported & {$[20]$} \\
\hline Phenothrin versus wet-combing & May be as effective & No evidence of harms from combing & {$[21]$} \\
\hline $\begin{array}{l}\text { Tocopheryl acetate versus } \\
\text { permethrin }\end{array}$ & More effective & No adverse effects reported & {$[22]$} \\
\hline Dimeticone versus permethrin & More effective & No serious adverse events & {$[23,24]$} \\
\hline Dimeticone versus malathion & More effective & No adverse effects reported & {$[25]$} \\
\hline $\begin{array}{l}\text { Dimeticone versus dimeticone plus } \\
\text { nerolidol }\end{array}$ & As effective & No adverse effects reported & {$[26]$} \\
\hline $\begin{array}{l}\text { Dimeticone } 4 \% \text { lotion versus } \\
\text { phenothrin }\end{array}$ & Equally effective & Few adverse effects reported & {$[27]$} \\
\hline Ivermectin versus malathion & As effective & No major adverse effects observed & {$[28,29]$} \\
\hline Ivermectin versus placebo (vehicle) & More effective & No adverse effects reported & {$[30]$} \\
\hline Malathion lotion versus phenothrin & More effective & No adverse effects reported & {$[31]$} \\
\hline Malathion versus permethrin & More effective & No adverse effects reported & {$[32]$} \\
\hline Lindane versus permethrin & As effective & Adverse effects reported & {$[33]$} \\
\hline Permethrin versus lindane & More effective & No adverse effects reported & {$[34]$} \\
\hline Permethrin versus combing & More effective & No adverse effects reported & {$[35]$} \\
\hline Permethrin versus placebo & More effective & No adverse effects reported & {$[36]$} \\
\hline $\begin{array}{l}\text { TMP-SMX plus permethrin versus } \\
\text { permethrin alone }\end{array}$ & More effective & No major adverse effects reported & {$[37]$} \\
\hline $\begin{array}{l}\text { Combined insecticides versus } \\
\text { herbal oils }\end{array}$ & As effective & No clinically detectable adverse effects & {$[38]$} \\
\hline $\begin{array}{l}\text { Soya oil-based shampoo versus } \\
\text { permethrin }\end{array}$ & More effective & No serious adverse events & {$[39]$} \\
\hline $\begin{array}{l}\text { Coconut and anise in spray versus } \\
\text { permethrin }\end{array}$ & More effective & Adverse effects reported & {$[40]$} \\
\hline Combing versus phenothrin & More effective & No evidence of harms from combing & {$[41]$} \\
\hline $\begin{array}{l}\text { Bug Buster kit versus malathion or } \\
\text { permethrin }\end{array}$ & More effective & No information on adverse effects & {$[42]$} \\
\hline
\end{tabular}

phenothrin, and bioallethrin) [82]. Most of these pediculicides were tested in clinical trials to assess their effectiveness and safety (Table 1). However, their pediculicidal and ovicidal efficacy may vary by product components (Table 2 ).

(1) Dichlorodiphenyltrichloroethane (DDT) and Lindane. Organochlorines (DDT and lindane) were the first of the synthetic organic insecticides used. The development of DDT during the 1940s had enormous impact. It was immediately used to dust prisoners of war to control body lice and won wide acceptance, not only for use on humans but also for animals [100]. Lindane has been available since 1951. However, its effectiveness has been compared to other products $[33,34]$. Physiological resistance among both head and body louse populations to lindane is widespread [101]. These two organochlorides are neurotoxic for parasites. Due to developed resistance [91] and safety concerns, the use of these products should be discussed [6].

(2) Malathion. An organophosphorous insecticide formulated in concentrations of $1.0 \%$ and $0.5 \%$, malathion, has been widely used in the USA and Europe. It worked rapidly against adult lice and was usually effective ovicide [102]. Its effectiveness has been tested in clinical trials [31, 32, 42]. However, resistance of body lice to malathion has been reported in Burundi [103] and Ethiopia [104]. In France, head lice resistance to malathion is reported to be based on clinical failure to control infestations [105]. In addition, a randomized study in 22 volunteers found no evidence that malathion was dangerous in the treatment of head lice when the products were applied in accordance with the instructions for use [106]. However, its use in children under 6 months should be avoided [6].

(3) Carbaryl. Used since 1976, more recent reviews have reported carbaryl to be less effective than previously thought [107]. Potentially carcinogenic in rodents, its prescription was restricted in UK [6].

(4) Natural Pyrethrins or Synthetic Pyrethroids (Phenothrin). These pyrethroids are closely related to permethrin and are combined with a synergist (piperonyl butoxide) or 
TABLE 2: Main formulations of physical acting and insecticide-based products available in France.

\begin{tabular}{|c|c|c|c|c|}
\hline Physical acting products & Principal component(s) & $\begin{array}{l}\text { Insecticide-based } \\
\text { products }\end{array}$ & $\begin{array}{c}\text { Principal } \\
\text { component(s) }\end{array}$ & Activity \\
\hline Pouxit $^{\circledR}$ XF Extra Fort & $\begin{array}{l}\text { Dimeticone-1.6, dodecatrien-3-ol } \\
\text { 3,7,11-trimetyl PEG/PPG dimeticone } \\
\text { co-polymersilica silylate }\end{array}$ & \multirow[t]{2}{*}{ Prioderm $^{\circledR}$} & \multirow[t]{2}{*}{ Malathion } & \multirow{2}{*}{$\begin{array}{l}100 \% \text { pediculicidal } \\
\text { and ovicidal } \\
\text { activity }\end{array}$} \\
\hline Duo LP Pro ${ }^{\circledR}$ & $\begin{array}{l}\text { Triglycerides, lipid esters } \\
\text { (Oxyphthirine) }\end{array}$ & & & \\
\hline $\operatorname{Itax}^{\circledR}$ & Oily silicone based complex & & & \multirow{6}{*}{$\begin{array}{l}100 \% \text { pediculicidal } \\
\text { activity and } \\
\text { insufficient } \\
\text { ovicidal activity }\end{array}$} \\
\hline Altopou $^{\circledR}$ & Cyclomethicone 5, dimeticone & Marie-Rose & Pyrethrin & \\
\hline Pouxit & Cyclomethicone 5, dimeticone & Para $^{\circledR}$ Special Poux & $\begin{array}{c}\text { Alethrin } \\
\text { (prallethrin) }\end{array}$ & \\
\hline Parani $x^{\circledR}$ mousse & Dimeticone, paraffin oil & Para Plus & $\begin{array}{l}\text { Malathion, } \\
\text { permethrin }\end{array}$ & \\
\hline $\begin{array}{l}\text { Paranix new formule } \\
\text { action double }\end{array}$ & Dimeticone, mineral oil & & & \\
\hline $\begin{array}{l}\text { Marie-Rose }{ }^{\circledR} \text { une seule } \\
\text { application }\end{array}$ & $\begin{array}{l}\text { Cocamidopropyl betaine cocamide } \\
\text { DEA }\end{array}$ & & & \\
\hline $\begin{array}{l}\text { Parasidose }{ }^{\circledR} \text { lotion } \\
\text { traitante }\end{array}$ & $\begin{array}{l}\text { Ricinus, paraffin, cocamide DEA, } \\
\text { cocos }\end{array}$ & Pyreflor ${ }^{\circledR}$ lotion & Permethrin 25/75 & \multirow{4}{*}{$\begin{array}{c}\text { Insufficient } \\
\text { pediculicidal } \\
\text { activity and } \\
\text { insufficient } \\
\text { ovicidal activity }\end{array}$} \\
\hline $\begin{array}{l}\text { Parasidose nouvelle } \\
\text { formule Biococidine }^{\circledR}\end{array}$ & Biococidine & Sklice ${ }^{\circledast}$ lotion & Ivermectin & \\
\hline Yapapou $^{\circledR}$ & $\begin{array}{l}\text { Cocos nucifera, cocamide DEA, } \\
\text { citric acid, cocamidopropyl }\end{array}$ & & & \\
\hline Poux Apaisyl ${ }^{\circledR}$ & Coconut oil derivatives & & & \\
\hline
\end{tabular}

nonsynergist insecticide (permethrin) [6]. Like malathion, these products can be a fire danger, and burns have been reported [108]. As with permethrin, resistance to this compound has already appeared in France [109], UK [110], and the Czech Republic [111]. In clinical trials, phenothrin has been demonstrated to also be more effective than wetcombing [21]. It seems likely that resistance to pyrethroids will develop much more rapidly than was the case with older compounds [112]. However, many studies worldwide have already described resistance to pyrethrins and pyrethroids $[91,99,113]$.

(5) Permethrin. Synthetic pyrethroid, introduced for the first time in the 1986s, $1 \%$ permethrin, was approved and was available over the counter for use in 1990 [114]. It is one of the most frequently used treatments against human ectoparasites (head lice and scabies) among lindane, malathion, and carbaryl $[34,115]$. However, resistance to permethrin has been reported in many studies throughout the world [116120]. In clinical trial, permethrin compared to soya oil-based shampoo, coconut, and anise in spray has been less effective $[39,40]$.

(6) Dimethicone. Some studies found dimethicone to be a safe product and more effective than permethrin [121]. In their randomized controlled trial, Burgess et al. confirm efficacy of a single application of $4 \%$ dimeticone liquid gel in comparison with two applications of $1 \%$ permethrin [23]. Used in many clinical trials, its effectiveness may depend on product $[24-27,122]$. However, resistance to dimethicone is unlikely due to its physical mode of action [114].
(7) Oxyphthirine ${ }^{\circledR}$. The Oxyphthirine lotion in a single application in treatment of human lice infestations was revealed to be the safest as it was shown to be nonflammable. The product showed a high efficiency $(100 \%)$ and certain ability to remove attached nits [123]. The lotion, a patented metaemulsion suitable for treatment of human head lice (Pediculus capitis), has a mechanical action that asphyxiates lice and nits [123].

(8) Benzyl Benzoate/Benzyl Alcohol. In concentrations of $10 \%$ to $30 \%$, this substance has been widely used for treatment of pediculosis and scabies, although it is not always effective ovicide. This product may cause allergic reactions and skin irritations. It is no longer registered for lice control in the USA, and in Canada it is only available on prescription [112]. Benzyl alcohol 5\% is nonneurotoxic and kills head lice by asphyxiation. Its side effects are pruritus, erythema, pyoderma, and ocular irritation [114].

(9) Spinosad. Spinosad $0.9 \%$ topical suspension is a new ovicidal and pediculicidal treatment against head lice created by fermenting Saccharopolyspora spinosa, a bacterium found in the soil [124]. However, the most common adverse reactions observed include erythema, ocular irritation, and irritation at the application site [125].

(10) Other Products. 1,2-Octanediol, cocamide diethanolamine lotion (cocamide DEA), and tocopheryl acetate $20 \%$ were tested in clinical trials against head lice to assess their efficiency and safety (Table 1) [18-20, 22]. However, the adverse effects were reported with 1,2-octanediol and 
cocamide diethanolamine except tocopheryl acetate. Thus, continued study is recommended to establish long-term safety of new and alternative agents [126].

3.3. Per Os Treatment. As all other external treatments, per os treatment may have more secondary effects.

3.3.1. Ivermectin. Macrocyclic lactone, ivermectin, is widely used throughout central and western Africa as a microfilaricide to control the transmission of human onchocerciasis and Bancroft filariasis and has been effective against ectoparasites and nematodes in veterinary medicine. It is similar to macrolide antibiotic agents but without antibacterial activity. Clinicians have explored using ivermectin for human ectoparasitics, specifically for head lice (and scabies). In clinical trials, its effectiveness has been compared to other products $[29,30]$. Ivermectin appears to provide encouraging results in the treatment of head lice [127] with a need for further doses [128], despite a potential resistance to this molecule being demonstrated in laboratory conditions [129]. However, in a cohort of homeless subjects in Marseilles, France, a prevalence of $85 \%$ for body lice was observed [130]. This infestation was reduced temporarily to $19 \%$ with three doses of oral ivermectin administered at seven-day intervals [130]. Currently, resistance to ivermectin has been widely demonstrated in many arthropods [131, 132] and is an increasing problem for ectoparasite and nematode control. In clinical trials, oral ivermectin, given twice at a 7-day interval, may be more effective [28] or as efficacious [29] as topical $0.5 \%$ malathion lotion.

3.3.2. Cotrimoxazole. Although this product (trimethoprim/sulfamethoxazole, TMP/SMX) has also been reported as a treatment in head lice [133], these compounds are not currently recommended for controlling body lice. Moreover, using this molecule as a pediculicide was stopped due to the multiple adverse effects (nausea, vomiting, rash, transient pruritus, and allergic-type reactions) recorded in participants in clinical trials [37].

\section{New Approaches}

The posttreatment reemergence of lice is common and still remains a real challenge. Treatment success depends on improving our knowledge of the fundamental biology and physiology of the louse.

It is important to notice that per os treatment may have more secondary effects as all other oral medicines than external products.

4.1. Symbiotic Treatment. Only a few P-endosymbionts have been described among 14,000 species of hematophagous insects $[134,135]$. The endosymbiont Candidatus Riesia pediculicola (Figure 3(a)) is a microorganism hosted by body (Pediculus humanus corporis) and head lice (Pediculus humanus capitis) that appears to be essential for the production of nutritional components such as the B vitamins lacking in host feeding $[3,4]$. In our laboratory, we developed an experimental in vitro feeding model using an artificial membrane to demonstrate that doxycycline (an antibiotic belonging to the family of tetracyclines) given at different doses $(10,20$, and $50 \mu \mathrm{g} / \mathrm{mL})$ daily for up to 10 days affects the endosymbiont of lice (Figure 3(b)) and also decreases egg production [136]. It was demonstrated that the symbiont Candidatus Riesia pediculicola is a possible target for the development of louse-control strategies [56], because loss of these bacteria would mean the death of their hosts. However, symbiotic treatment remains promising and it would be interesting to evaluate the effectiveness of other drugs alone or in combination on lice by targeting their endosymbiont bacterium.

\subsection{Synergistic Treatment (Antibiotics + Ivermectin): Figures} 3(c) and 3(d). Several compounds, including antibiotics, have been shown to increase intracellular concentrations of macrocyclic lactones [137]. Indeed, antibiotics such as doxycycline, erythromycin, or azithromycin were recommended to treat some infections linked to lice [138]. In addition, it was shown that drug combinations including ivermectin provide antifilarial activity with ancillary benefits on intestinal helminths and ectoparasites, such as chiggers and lice [139]. However, in experiments with adult worms, when doxycycline was combined with macrocyclic lactones in ivermectin the effectiveness was approximately $80 \%$ versus $9 \%$ for treatment with doxycycline alone $[140,141]$. The effectiveness of this combination has also been confirmed in naturally infected dogs with Dirofilaria immitis [142]. Recently, in our laboratory we have demonstrated the effectiveness of drug combinations (especially doxycycline + ivermectin, erythromycin + ivermectin, rifampicin + ivermectin, and azithromycin + ivermectin) on body lice reared on rabbits in our laboratory [143]. Thus, we conclude that the synergistic effect is one of the most effective means of lice treatment and also prevents reemergence and resistance.

\section{Future Efforts}

Lice have been intimately associated with humans for centuries. Infestations are increasing worldwide due to insecticide resistance. To date, viable alternative treatments to replace insecticides have been developed experimentally in vitro. However, it will be interesting to develop these methods in vivo in other studies in order to achieve the complete eradication of lice and avoid the selection of a resistant population of lice. Thus, future efforts should be directed toward the development of pediculicides based on new chemicals such as avermectins and antibiotics.

\section{Competing Interests}

The authors declared that there is no conflict of interests.

\section{Authors' Contributions}

Abdoul Karim Sangaré, Ogobara K. Doumbo, and Didier Raoult conceived and wrote the final version of the paper. 


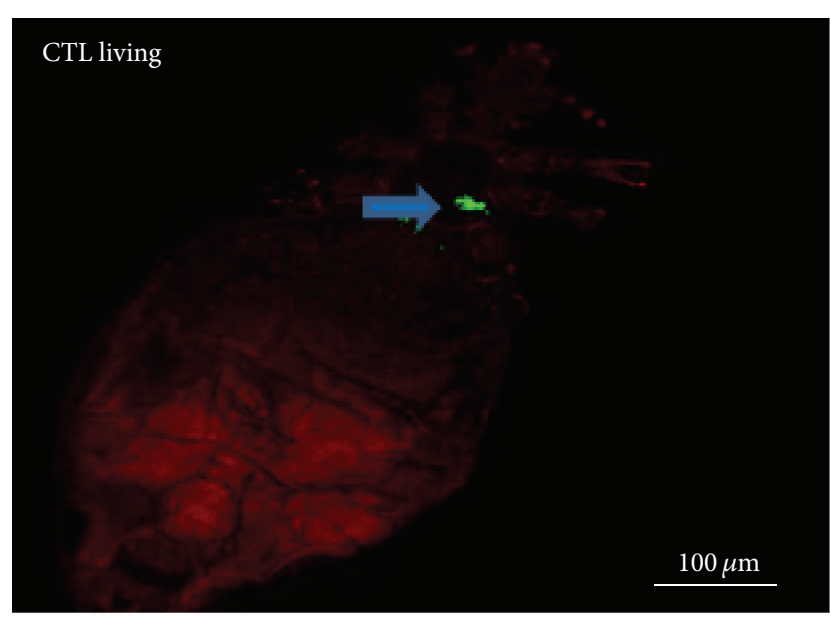

(a)

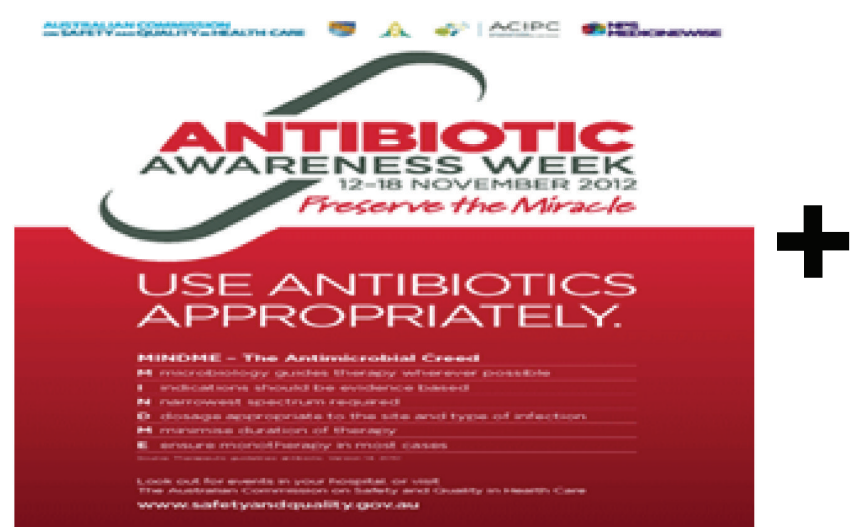

(c)

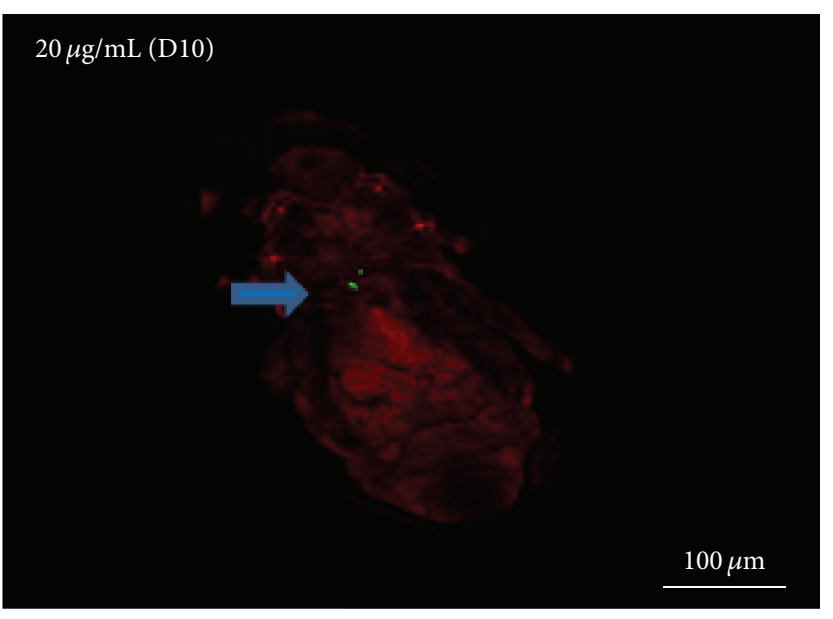

(b)

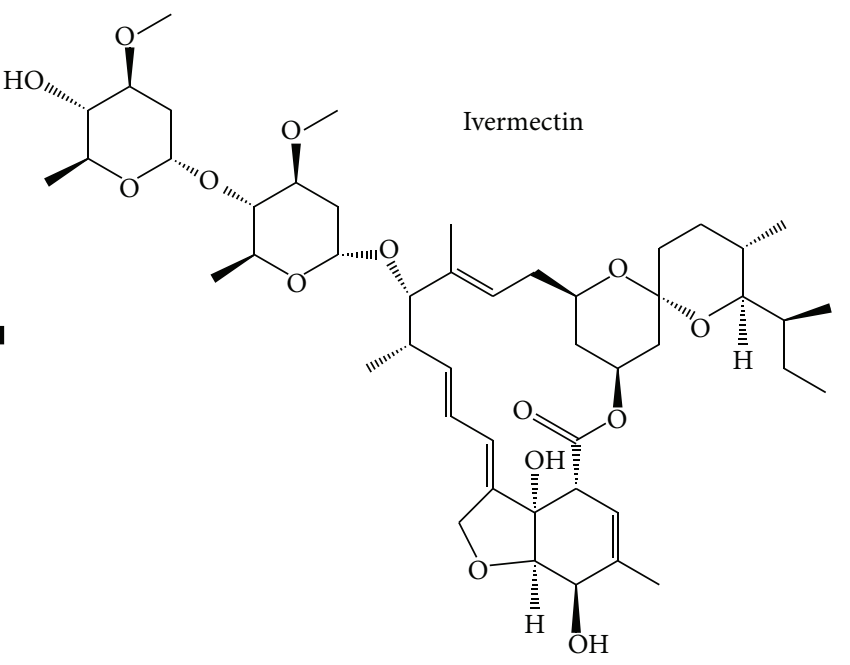

(d)

FIGURE 3: New approaches to get rid of lice: symbiotic treatment ((a) living control showing higher bacterial fluorescence; (b) louse treated with doxycycline $20 \mu \mathrm{g} / \mathrm{mL}$ taken at day 10 showing lower bacterial fluorescence) and synergistic treatment ((c) antibiotics; (d) ivermectin: chemical structure).

\section{Acknowledgments}

This work was supported by IHU Méditerranée Infection, Marseille, France.

\section{References}

[1] J. E. Light, M. A. Toups, and D. L. Reed, "What's in a name: the taxonomic status of human head and body lice," Molecular Phylogenetics and Evolution, vol. 47, no. 3, pp. 1203-1216, 2008.

[2] H. D. Pratt and K. Littig, Public Health Importance, 1973.

[3] P. Buchner, "Zur kenntnis der symbiose niederer pflanzlicher organismen mit pedikuliden," Biologisches Zentralblatt, vol. 39, pp. 535-540, 1920.

[4] H. Sikora, "Vorläufige Mitteilungen über Mycetome bei Pediculiden," Biologisches Zentralblatt, vol. 39, pp. 287-288, 1919.

[5] K. Sasaki-Fukatsu, R. Koga, N. Nikoh et al., "Symbiotic bacteria associated with stomach discs of human lice," Applied and Environmental Microbiology, vol. 72, no. 11, pp. 7349-7352, 2006.
[6] O. Chosidow, "Scabies and pediculosis," The Lancet, vol. 355, no. 9206, pp. 819-826, 2000.

[7] L. Wadowski, L. Balasuriya, H. N. Price, and J. O'Haver, "Lice update: new solutions to an old problem," Clinics in Dermatology, vol. 33, no. 3, pp. 347-354, 2015.

[8] Y. V. Lopatina, "Pediculosis: current aspects of the old problem," Meditsinskaya Parazitologiya i Parazitarnye Bolezni, no. 2, pp. 44-51, 2015.

[9] J. W. Maunder, "The appreciation of lice," Proceedings of the Royal Institution of Great Britain, vol. 55, pp. 1-31, 1983.

[10] J. Droogan, "Treatment and prevention of head lice and scabies," Nursing Times, vol. 95, no. 29, pp. 44-45, 1999.

[11] B. L. Frankowski and L. B. Weiner, "Head lice," Pediatrics, vol. 110, pp. 638-643, 2002.

[12] I. F. Burgess, "Head lice," BMJ Clinical Evidence, vol. 2009, 2009.

[13] I. F. Burgess, "Human lice and their management," Advances in Parasitology, vol. 36, pp. 271-342, 1995.

[14] T. L. Meinking and D. Taplin, "Infestations: pediculosis," Current Problems in Dermatology, vol. 24, pp. 157-163, 1996. 
[15] D. Raoult, J. B. Ndihokubwayo, H. Tissot-Dupont et al., "Outbreak of epidemic typhus associated with trench fever in Burundi," The Lancet, vol. 352, no. 9125, pp. 353-358, 1998.

[16] D. Raoult, O. Dutour, L. Houhamdi et al., "Evidence for lousetransmitted diseases in soldiers of Napoleon's Grand Army in Vilnius," The Journal of Infectious Diseases, vol. 193, no. 1, pp. 112-120, 2006.

[17] V. Roux and D. Raoult, "Body lice as tools for diagnosis and surveillance of reemerging diseases," Journal of Clinical Microbiology, vol. 37, no. 3, pp. 596-599, 1999.

[18] I. F. Burgess, P. N. Lee, K. Kay, R. Jones, and E. R. Brunton, "1,2-octanediol, a novel surfactant, for treating head louse infestation: identification of activity, formulation, and randomised, controlled trials," PLoS ONE, vol. 7, no. 4, Article ID e35419, 2012.

[19] I. F. Burgess, E. R. Brunton, R. French, and N. A. Burgess, "Prevention of head louse infestation: a randomised, doubleblind, cross-over study of a novel concept product, 1\% 1,2octanediol spray versus placebo," BMJ Open, vol. 4, no. 5, Article ID e004634, 2014.

[20] I. F. Burgess, E. R. Brunton, and C. M. Brown, "Laboratory and clinical trials of cocamide diethanolamine lotion against head lice," PeerJ, vol. 2015, no. 11, Article ID e1368, 2015.

[21] I. F. Burgess, C. M. Brown, and P. Nair, "Comparison of phenothrin mousse, phenothrin lotion, and wet-combing for treatment of head louse infestation in the UK: a pragmatic randomised, controlled, assessor blind trial," F1000Research, vol. 3, article 158, 2014.

[22] I. F. Burgess, N. A. Burgess, and E. R. Brunton, “Tocopheryl acetate $20 \%$ spray for elimination of head louse infestation: a randomised controlled trial comparing with $1 \%$ permethrin creme rinse," BMC Pharmacology and Toxicology, vol. 14, article 43, 2013.

[23] I. F. Burgess, E. R. Brunton, and N. A. Burgess, "Single application of $4 \%$ dimeticone liquid gel versus two applications of $1 \%$ permethrin creme rinse for treatment of head louse infestation: a randomised controlled trial," BMC Dermatology, vol. 13, article 5, 2013.

[24] R. Speare, "A single application of dimeticone is superior to two applications of permethrin in ridding head lice," Journal of Pediatrics, vol. 163, no. 5, pp. 1531-1532, 2013.

[25] I. F. Burgess, P. N. Lee, and G. Matlock, "Randomised, controlled, assessor blind trial comparing $4 \%$ dimeticone lotion with $0.5 \%$ malathion liquid for head louse infestation," PLoS ONE, vol. 2, no. 11, Article ID el127, 2007.

[26] Ö. Kurt, I. C. Balcioglu, I. F. Burgess et al., “Treatment of head lice with dimeticone $4 \%$ lotion: comparison of two formulations in a randomised controlled trial in rural Turkey," BMC Public Health, vol. 9, article 441, 2009.

[27] I. F. Burgess, C. M. Brown, and P. N. Lee, "Treatment of head louse infestation with $4 \%$ dimeticone lotion: randomised controlled equivalence trial," British Medical Journal, vol. 330, no. 7505, pp. 1423-1425, 2005.

[28] O. Chosidow, B. Giraudeau, J. Cottrell et al., "Oral ivermectin versus malathion lotion for difficult-to-treat head lice," The New England Journal of Medicine, vol. 362, no. 10, pp. 896-905, 2010.

[29] A. Nofal, "Oral ivermectin for head lice: a comparison with $0.5 \%$ topical malathion lotion," Journal of the German Society of Dermatology, vol. 8, no. 12, pp. 985-989, 2010.

[30] D. M. Pariser, T. L. Meinking, M. Bell, and W. G. Ryan, "Topical $0.5 \%$ ivermectin lotion for treatment of head lice," The New England Journal of Medicine, vol. 367, no. 18, pp. 1687-1693, 2012.
[31] O. Chosidow, C. Chastang, C. Brue et al., "Controlled study of malathion and d-phenothrin lotions for Pediculus humanus var capitis-infested schoolchildren," The Lancet, vol. 344, no. 89398940, pp. 1724-1727, 1994.

[32] T. L. Meinking, M. Vicaria, D. H. Eyerdam, M. E. Villar, S. Reyna, and G. Suarez, "Efficacy of a reduced application time of ovide lotion ( $0.5 \%$ malathion) compared to nix creme rinse ( $1 \%$ permethrin) for the treatment of head lice," Pediatric Dermatology, vol. 21, no. 6, pp. 670-674, 2004.

[33] D. C. Kalter, J. Sperber, T. Rosen, and S. Matarasso, “Treatment of pediculosis pubis. Clinical comparison of efficacy and tolerance of $1 \%$ lindane shampoo vs $1 \%$ permethrin creme rinse," Archives of Dermatology, vol. 123, no. 10, pp. 1315-1319, 1987.

[34] R. H. Vander Stichele, E. M. Dezeure, and M. G. Bogaert, "Systematic review of clinical efficacy of topical treatments for head lice," The British Medical Journal, vol. 311, no. 7005, pp. 604-608, 1995.

[35] T. L. Meinking, C. M. Clineschmidt, C. Chen et al., "An observer-blinded study of $1 \%$ permethrin creme rinse with and without adjunctive combing in patients with head lice," The Journal of Pediatrics, vol. 141, no. 5, pp. 665-670, 2002.

[36] S. Benkouiten, R. Drali, S. Badiaga et al., "Effect of permethrinimpregnated underwear on body lice in sheltered homeless persons: a randomized controlled trial," JAMA Dermatology, vol. 150, no. 3, pp. 273-279, 2014.

[37] R. B. Hipolito, F. G. Mallorca, Z. O. Zuniga-Macaraig, P. C. Apolinario, and J. Wheeler-Sherman, "Head lice infestation: single drug versus combination therapy with one percent permethrin and trimethoprim/sulfamethoxazole," Pediatrics, vol. 107, no. 3, article E30, 2001.

[38] K. Y. Mumcuoglu, J. Miller, C. Zamir, G. Zentner, V. Helbin, and A. Ingber, "The in vivo pediculicidal efficacy of a natural remedy," Israel Medical Association Journal, vol. 4, no. 10, pp. 790-793, 2002.

[39] I. F. Burgess, K. Kay, N. A. Burgess, and E. R. Brunton, "Soya oil-based shampoo superior to $0.5 \%$ permethrin lotion for head louse infestation," Medical Devices: Evidence and Research, vol. 4, no. 1, pp. 35-42, 2011.

[40] I. F. Burgess, E. R. Brunton, and N. A. Burgess, "Clinical trial showing superiority of a coconut and anise spray over permethrin $0.43 \%$ lotion for head louse infestation, ISRCTN96469780," European Journal of Pediatrics, vol. 169, no. 1, pp. 55-62, 2010.

[41] L. Plastow, M. Luthra, R. Powell, J. Wright, D. Russell, and M. N. Marshall, "Head lice infestation: bug busting vs. traditional treatment," Journal of Clinical Nursing, vol. 10, no. 6, pp. 775$783,2001$.

[42] N. Hill, G. Moor, M. M. Cameron et al., "Single blind, randomised, comparative study of the Bug Buster kit and over the counter pediculicide treatments against head lice in the United Kingdom," British Medical Journal, vol. 331, no. 7513, pp. 384386, 2005.

[43] D. Raoult and V. Roux, "The body louse as a vector of reemerging human diseases," Clinical Infectious Diseases, vol. 29, no. 4, pp. 888-911, 1999.

[44] Z. Yong, P.-É. Fournier, E. Rydkina, and D. Raoult, "The geographical segregation of human lice preceded that of Pediculus humanus capitis and Pediculus humanus humanus," Comptes Rendus Biologies, vol. 326, no. 6, pp. 565-574, 2003.

[45] R. Kittler, M. Kayser, and M. Stoneking, "Molecular evolution of Pediculus humanus and the origin of clothing," Current Biology, vol. 13, no. 16, pp. 1414-1417, 2003. 
[46] D. Raoult, D. L. Reed, K. Dittmar et al., "Molecular identification of lice from pre-Columbian mummies," The Journal of Infectious Diseases, vol. 197, no. 4, pp. 535-543, 2008.

[47] D. L. Reed, V. S. Smith, S. L. Hammond, A. R. Rogers, and D. H. Clayton, "Genetic analysis of lice supports direct contact between modern and archaic humans," PLoS Biology, vol. 2, no. 11, article e340, 2004.

[48] W. Li, G. Ortiz, P.-E. Fournier et al., "Genotyping of human lice suggests multiple emergences of body lice from local head louse populations," PLoS Neglected Tropical Diseases, vol. 4, no. 3, article e641, 2010.

[49] A. Veracx, A. Boutellis, V. Merhej, G. Diatta, and D. Raoult, "Evidence for an African cluster of human head and body lice with variable colors and interbreeding of lice between continents," PLoS ONE, vol. 7, no. 5, Article ID e37804, 2012.

[50] R. Drali, J.-C. Shako, B. Davoust, G. Diatta, and D. Raoult, "A new clade of African body and head lice infected by Bartonella quintana and Yersinia pestis-Democratic Republic of the Congo," The American Journal of Tropical Medicine and Hygiene, vol. 93, no. 5, pp. 990-993, 2015.

[51] B. P. Olds, B. S. Coates, L. D. Steele et al., "Comparison of the transcriptional profiles of head and body lice," Insect Molecular Biology, vol. 21, no. 2, pp. 257-268, 2012.

[52] A. Veracx and D. Raoult, "Biology and genetics of human head and body lice," Trends in Parasitology, vol. 28, no. 12, pp. 563571, 2012.

[53] R. Drali, A. Boutellis, D. Raoult, J. M. Rolain, and P. Brouqui, "Distinguishing body lice from head lice by multiplex real-time PCR analysis of the phum_PHUM540560 gene," PLoS ONE, vol. 8, no. 2, Article ID e58088, 2013.

[54] H. E. Ewing, "A revision of the American lice of the genus Pediculus, together with aconsideration of the significance of their geographical and host distribution," Proceedings of the United States National Museum, vol. 68, no. 2620, pp. 1-30, 1926.

[55] M. A. Perotti, J. M. Allen, D. L. Reed, and H. R. Braig, "Hostsymbiont interactions of the primary endosymbiont of human head and body lice," The FASEB Journal, vol. 21, no. 4, pp. 10581066, 2007.

[56] E. F. Kirkness, B. J. Haas, W. Sun et al., "Genome sequences of the human body louse and its primary endosymbiont provide insights into the permanent parasitic lifestyle," Proceedings of the National Academy of Sciences of the United States of America, vol. 107, no. 27, pp. 12168-12173, 2010.

[57] D. Raoult, R. J. Birtles, M. Montoya et al., "Survey of three bacterial louse-associated diseases among rural Andean communities in Peru: prevalence of epidemic typhus, trench fever, and relapsing fever," Clinical Infectious Diseases, vol. 29, no. 2, pp. 434-436, 1999.

[58] I. Tarasevich, E. Rydkina, and D. Raoult, "Outbreak of epidemic typhus in Russia," The Lancet, vol. 352, no. 9134, p. 1151, 1998.

[59] S. Badiaga, A. Menard, H. Tissot Dupont et al., "Prevalence of skin infections in sheltered homeless," European Journal of Dermatology, vol. 15, no. 5, pp. 382-386, 2005.

[60] P. Brouqui, A. Stein, H. T. Dupont et al., "Ectoparasitism and vector-borne diseases in 930 homeless people from Marseilles," Medicine, vol. 84, no. 1, pp. 61-68, 2005.

[61] E. B. Rydkina, V. Roux, E. M. Gagua, A. B. Predtechenski, I. V. Tarasevich, and D. Raoult, "Bartonella quintana in body lice collected from homeless persons in Russia," Emerging Infectious Diseases, vol. 5, no. 1, pp. 176-178, 1999.
[62] N. Seki, T. Sasaki, K. Sawabe et al., "Epidemiological studies on Bartonella quintana infections among homeless people in Tokyo, Japan," Japanese Journal of Infectious Diseases, vol. 59, no. 1, pp. 31-35, 2006.

[63] D. H. Spach, A. S. Kanter, M. J. Dougherty et al., "Bartonella (Rochalimaea) quintana bacteremia in inner-city patients with chronic alcoholism," The New England Journal of Medicine, vol. 332, no. 7, pp. 424-428, 1995.

[64] J. H. Kim, J. S. Min, J. S. Kang et al., "Comparison of the humoral and cellular immune responses between body and head lice following bacterial challenge," Insect Biochemistry and Molecular Biology, vol. 41, no. 5, pp. 332-339, 2011.

[65] D. L. Bonilla, H. Kabeya, J. Henn, V. L. Kramer, and M. Y. Kosoy, "Bartonella quintana in body lice and head lice from homeless persons, San Francisco, California, USA," Emerging Infectious Diseases, vol. 15, no. 6, pp. 912-915, 2009.

[66] B. La Scola and D. Raoult, "Acinetobacter baumannii in human body louse," Emerging Infectious Diseases, vol. 10, no. 9, pp. 16711673, 2004.

[67] M. Drancourt, L. Houhamdi, and D. Raoult, "Yersinia pestis as a telluric, human ectoparasite-borne organism," The Lancet Infectious Diseases, vol. 6, no. 4, pp. 234-241, 2006.

[68] L. Houhamdi and D. Raoult, "Different genes govern Yersinia pestis pathogenicity in Caenorhabditis elegans and human lice," Microbial Pathogenesis, vol. 44, no. 5, pp. 435-437, 2008.

[69] R. Piarroux, A. A. Abedi, J.-C. Shako et al., "Plague epidemics and lice, Democratic Republic of the Congo," Emerging Infectious Diseases, vol. 19, no. 3, pp. 505-506, 2013.

[70] L. Houhamdi, H. Lepidi, M. Drancourt, and D. Raoult, "Experimental model to evaluate the human body louse as a vector of plague," Journal of Infectious Diseases, vol. 194, no. 11, pp. 15891596, 2006.

[71] T. Sasaki, S. K. S. Poudel, H. Isawa et al., "First molecular evidence of Bartonella quintana in Pediculus humanus capitis (Phthiraptera: Pediculidae), collected from Nepalese children," Journal of Medical Entomology, vol. 43, no. 1, pp. 110-112, 2006.

[72] A. K. Sangaré, A. Boutellis, R. Drali et al., "Detection of Bartonella quintana in African body and head lice," The American Journal of Tropical Medicine and Hygiene, vol. 91, no. 2, pp. 294301, 2014.

[73] E. Angelakis, J.-M. Rolain, D. Raoult, and P. Brouqui, "Bartonella quintana in head louse nits," FEMS Immunology and Medical Microbiology, vol. 62, no. 2, pp. 244-246, 2011.

[74] E. Angelakis, G. Diatta, A. Abdissa et al., "Altitude-dependent Bartonella quintana genotype $\mathrm{C}$ in head lice, Ethiopia," Emerging Infectious Diseases, vol. 17, no. 12, pp. 2357-2359, 2011.

[75] A. Boutellis, A. Veracx, E. Angelakis et al., "Bartonella quintana in head lice from Sénégal," Vector-Borne and Zoonotic Diseases, vol. 12, no. 7, pp. 564-567, 2012.

[76] S. Bouvresse, C. Socolovshi, Z. Berdjane et al., "No evidence of Bartonella quintana but detection of Acinetobacter baumannii in head lice from elementary schoolchildren in Paris," Comparative Immunology, Microbiology and Infectious Diseases, vol. 34, no. 6, pp. 475-477, 2011.

[77] A. K. Sangaré, S. N. Doumbo, A. K. Koné et al., "Lice in Mali: frequency of infestation, genotyping, infection rate and case management," Medecine et Sante Tropicales, vol. 25, no. 2, pp. 189-193, 2015.

[78] R. N. Chunge, F. E. Scott, J. E. Underwood, and K. J. Zavarella, "A review of the epidemiology, public health importance, treatment and control of head lice," Canadian Journal of Public Health, vol. 82, no. 3, pp. 196-200, 1991. 
[79] K. E. Forsman, "Pediculosis and scabies. What to look for in patients who are crawling with clues," Postgraduate Medicine, vol. 98 , no. 6, pp. 89-100, 1995.

[80] K. Y. Mumcuoglu, M. Friger, I. Ioffe-Uspensky, F. Ben-Ishai, and J. Miller, "Louse comb versus direct visual examination for the diagnosis of head louse infestations," Pediatric Dermatology, vol. 18, no. 1, pp. 9-12, 2001.

[81] C. Balcioglu, I. F. Burgess, M. E. Limoncu et al., "Plastic detection comb better than visual screening for diagnosis of head louse infestation," Epidemiology \& Infection, vol. 136, no. 10, pp. 1425-1431, 2008.

[82] K. Y. Mumcuoglu, "Control of human lice (Anoplura: Pediculidae) infestations: past and present," American Entomologist, vol. 42, no. 3, pp. 175-178, 1996.

[83] F. X. Pajot, Les Poux (Insecta, Anoplura) de la Région Afrotropicale, IRD Editions, 2000.

[84] J. Ibarra and D. M. B. Hall, "Head lice in schoolchildren," Archives of Disease in Childhood, vol. 75, no. 6, pp. 471-473, 1996.

[85] R. C. Hansen, "Overview: the state of head lice management and control," The American Journal of Managed Care, vol. 10, no. 9, pp. S260-263, 2004.

[86] A. W. Bacot, “The Louse problem," Proceedings of the Royal Society of Medicine, vol. 10, pp. 61-94, 1917.

[87] R. Thorsen, "Method and system for kiling lice and nits," Google Patents, 2007.

[88] J. R. Rutkauskis, D. Jacomini, L. G. Temponi, M. H. Sarragiotto, E. A. A. da Silva, and T. C. M. Jorge, "Pediculicidal treatment using ethanol and Melia azedarach L," Parasitology Research, vol. 114, no. 6, pp. 2085-2091, 2015.

[89] I. Burgess and C. M. Brown, Management of insecticide resistance in head lice Pediculus capitis (Anoplura: Pediculicidae), 1999, pp. 19-22.

[90] I. F. Burgess and C. M. Brown, "Measuring insecticide resistance in human head lice, Pediculus capitis (Anoplura: Pediculidae)," in Proceedings of the 3rd International Conference on Urban Pests, p. 634, July 1999.

[91] J. Hemingway, J. Miller, and K. Y. Mumcuoglu, "Pyrethroid resistance mechanisms in the head louse Pediculus capitis from Israel: Implications for control," Medical and Veterinary Entomology, vol. 13, no. 1, pp. 89-96, 1999.

[92] S. H. Lee, K.-S. Yoon, M. S. Williamson et al., "Molecular analysis of kdr-like resistance in permethrin-resistant strains of head lice, Pediculus capitis," Pesticide Biochemistry and Physiology, vol. 66, no. 2, pp. 130-143, 2000.

[93] R. J. Pollack, A. Kiszewski, P. Armstrong et al., "Differential permethrin susceptibility of head lice sampled in the United States and Borneo," Archives of Pediatrics and Adolescent Medicine, vol. 153, no. 9, pp. 969-973, 1999.

[94] World Health Organization, Instructions for Determing the Susceptibility or Resistance of Body Lice and Head Lice to Insecticides, World Health Organization, Geneva, Switzerland, 1981.

[95] I. F. Burgess, "Human lice and their control," Annual Review of Entomology, vol. 49, pp. 457-481, 2004.

[96] T. L. Meinking, P. Entzel, M. E. Villar, M. Vicaria, G. A. Lemard, and S. L. Porcelain, "Comparative efficacy of treatments for pediculosis capitis infestations: update 2000," Archives of Dermatology, vol. 137, no. 3, pp. 287-292, 2001.

[97] T. L. Meinking, D. Taplin, D. C. Kalter, and M. W. Eberle, "Comparative efficacy of treatments for pediculosis capitis infestations," Archives of Dermatology, vol. 122, no. 3, pp. 267271, 1986.
[98] World Health Organization, Resistance of Vectors and Reservoirs of Disease to Pesticides, World Health Organization, Geneva, Switzerland, 1976.

[99] A. M. R. Downs, K. A. Stafford, I. Harvey, and G. C. Coles, "Evidence for double resistance to permethrin and malathion in head lice," British Journal of Dermatology, vol. 141, no. 3, pp. 508-511, 1999.

[100] G. Levot, "Resistance and the control of lice on humans and production animals," International Journal for Parasitology, vol. 30, no. 3, pp. 291-297, 2000.

[101] J. W. Maunder, "Strategic aspects of insecticide resistance in head lice," Journal of the Royal Society of Health, vol. 111, no. 1, pp. 24-26, 1991.

[102] S. I. Rahlenbeck and A. Gebre-Yohannes, "Louse-borne relapsing fever and its treatment," Tropical and Geographical Medicine, vol. 47, no. 2, pp. 49-52, 1995.

[103] R. N. Miller, C. L. Wisseman Jr., G. W. Sweeney, A. Verschueren, and I. B. Fabrikant, "First report of resistance of human body lice to malathion," Transactions of the Royal Society of Tropical Medicine and Hygiene, vol. 66, no. 2, pp. 372-375, 1972.

[104] L. L. Sholdt, D. J. Seibert, M. L. Holloway, M. M. Cole, and D. E. Weidhaas, "Resistance of human body lice to malathion in Ethiopia," Transactions of the Royal Society of Tropical Medicine and Hygiene, vol. 70, no. 5-6, pp. 532-533, 1976.

[105] M. A. Izri and C. Brière, "First cases of resistance of Pediculus capitis Linné 1758 to malathion in France," Presse Médicale, vol. 24, no. 31, p. 1444, 1995.

[106] G. A. Dennis and P. N. Lee, "A phase I volunteer study to establish the degree of absorption and effect on cholinesterase activity of four head lice preparations containing malathion," Clinical Drug Investigation, vol. 18, no. 2, pp. 105-115, 1999.

[107] I. Burgess, "Carbaryl lotions for head lice-new laboratory tests show variations in efficacy," Pharmaceutical Journal, vol. 245, pp. 159-161, 1990.

[108] S. Choudhary, "Burns due to anti-lice lotion," Burns, vol. 25, no. 2, pp. 184-185, 1999.

[109] J. Coz, C. Combescot-Lang, and V. Verdier, "Resistance du pou de tête Pediculus capitis L. 1758 aux Pyrethrinoides: DPhenothrine et Permethrine en France," Bulletin de la Societé Française de Parasitologie, vol. 11, pp. 245-252, 1993.

[110] I. F. Burgess, C. M. Brown, S. Peock, and J. Kaufman, "Head lice resistant to pyrethroid insecticides in Britain," The British Medical Journal, vol. 311, no. 7007, p. 752, 1995.

[111] V. Rupes, J. Moravec, J. Chmela, J. Ledvinka, and J. Zelenkova, "A resistance of head lice (Pediculus capitis) to permethrin in Czech Republic," Central European Journal of Public Health, vol. 3, no. 1, pp. 30-32, 1995.

[112] N. G. Gratz, Human Lice-Their Prevalence, Control and Resistance to Insecticides: A Review 1985-1997, 1997.

[113] L. A. Schachner, "Treatment resistant head lice: alternative therapeutic approaches," Pediatric Dermatology, vol. 14, no. 5, pp. 409-410, 1997.

[114] P. Verma and C. Namdeo, "Treatment of pediculosis capitis," Indian Journal of Dermatology, vol. 60, no. 3, pp. 238-247, 2015.

[115] D. Tomalik-Scharte, A. Lazar, J. Meins et al., "Dermal absorption of permethrin following topical administration," European Journal of Clinical Pharmacology, vol. 61, no. 5-6, pp. 399-404, 2005.

[116] R. Drali, S. Benkouiten, S. Badiaga, I. Bitam, J. M. Rolain, and P. Brouqui, "Detection of a knockdown resistance mutation associated with permethrin resistance in the body louse Pediculus 
humanus corporis by use of melting curve analysis genotyping," Journal of Clinical Microbiology, vol. 50, no. 7, pp. 2229-2233, 2012.

[117] J. Hemingway and H. Ranson, "Insecticide resistance in insect vectors of human disease," Annual Review of Entomology, vol. 45, pp. 371-391, 2000.

[118] M. Lebwohl, L. Clark, and J. Levitt, "Therapy for head lice based on life cycle, resistance, and safety considerations," Pediatrics, vol. 119, no. 5, pp. 965-974, 2007.

[119] T. L. Meinking, L. Serrano, B. Hard et al., "Comparative in vitro pediculicidal efficacy of treatments in a resistant head lice population in the United States," Archives of Dermatology, vol. 138, no. 2, pp. 220-224, 2002.

[120] K. S. Yoon, J.-R. Gao, S. H. Lee, J. M. Clark, L. Brown, and D. Taplin, "Permethrin-resistant human head lice, Pediculus capitis, and their treatment," Archives of Dermatology, vol. 139, no. 8, pp. 994-1000, 2003.

[121] J. Heukelbach, D. Pilger, F. A. Oliveira, A. Khakban, L. Ariza, and H. Feldmeier, "A highly efficacious pediculicide based on dimeticone: randomized observer blinded comparative trial," BMC Infectious Diseases, vol. 8, article 115, 2008.

[122] E. S. Ihde, J. R. Boscamp, M. J. Loh, and L. Rosen, "Safety and efficacy of a $100 \%$ dimethicone pediculocide in school-age children," BMC Pediatrics, vol. 15, article 70, 2015.

[123] F. M. de Sousa, A. W. Vasconcelos, J. de Nadon, and P.-Y. Duhot, "Treatment of human head lice infestations in a single application with a new galenic lotion," International Journal of Cosmetic Science, vol. 32, no. 5, pp. 369-375, 2010.

[124] S. C. Villegas, "Spinosad for the treatment of head lice infestations," Drugs of Today, vol. 48, no. 9, pp. 595-599, 2012.

[125] D. Stough, S. Shellabarger, J. Quiring, and A. A. Gabrielsen Jr., "Efficacy and safety of spinosad and permethrin creme rinses for pediculosis capitis (head lice)," Pediatrics, vol. 124, no. 3, pp. e389-e395, 2009.

[126] B. Bohl, J. Evetts, K. McClain, A. Rosenauer, and E. Stellitano, "Clinical practice update: pediculosis capitis," Pediatric Nursing, vol. 41, no. 5, pp. 227-234, 2015.

[127] D. M. Pariser, T. L. Meinking, and W. G. Ryan, "Topical ivermectin lotion for head lice," The New England Journal of Medicine, vol. 368, article 967, 2013.

[128] P. Glaziou, L. N. Nyguyen, J. P. Moulia-Pelat, J. L. Cartel, and P. M. V. Martin, "Efficacy of ivermectin for the treatment of head lice (Pediculosis capitis)," Tropical Medicine and Parasitology, vol. 45, no. 3, pp. 253-254, 1994.

[129] K. S. Yoon, J. P. Strycharz, J. H. Baek et al., "Brief exposures of human body lice to sublethal amounts of ivermectin overtranscribes detoxification genes involved in tolerance," Insect Molecular Biology, vol. 20, no. 6, pp. 687-699, 2011.

[130] C. Foucaulf, S. Ranque, S. Badiaga, C. Rovery, D. Raoult, and P. Brouqui, "Oral ivermectin in the treatment of body lice," Journal of Infectious Diseases, vol. 193, no. 3, pp. 474-476, 2006.

[131] J. M. Clark, J. G. Scott, F. Campos, and J. R. Bloomquist, "Resistance to avermectins: extent, mechanisms, and management implications," Annual Review of Entomology, vol. 40, pp. 1-30, 1995.

[132] J. G. Scott, "Cross-resistance to the biological insecticide abamectin in pyrethroid-resistant house flies," Pesticide Biochemistry and Physiology, vol. 34, no. 1, pp. 27-31, 1989.

[133] C. H. Shashindran, I. S. Gandhi, S. Krishnasamy, and M. N. Ghosh, "Oral therapy of pediculosis capitis with cotrimoxazole," British Journal of Dermatology, vol. 98, no. 6, pp. 699-700, 1978.
[134] T. S. Adams, "Hematophagy and hormone release," Annals of the Entomological Society of America, vol. 92, no. 1, pp. 1-13, 1999.

[135] M. J. Lehane, The Biology of Blood-Sucking in Insects, Cambridge University Press, New York, NY, USA, 2005.

[136] A. K. Sangaré, A. Boutellis, R. Drali et al., "Doxycycline kills human lice through its activity on their bacterial symbiont," International Journal of Antimicrobial Agents, vol. 45, no. 6, pp. 675-676, 2015.

[137] J. Dupuy, A. Lespine, J. F. Sutra, and M. Alvinerie, "Fumagillin, a new P-glycoprotein-interfering agent able to modulate moxidectin efflux in rat hepatocytes," Journal of Veterinary Pharmacology and Therapeutics, vol. 29, no. 6, pp. 489-494, 2006.

[138] M. E. Ohl and D. H. Spach, "Bartonella quintana and urban trench fever," Clinical Infectious Diseases, vol. 31, no. 1, pp. 131$135,2000$.

[139] A. Munirathinam, I. P. Sunish, R. Rajendran, and B. K. Tyagi, "Impact of ivermectin drug combinations on Pediculus humanus capitis infestation in primary schoolchildren of south Indian rural villages," International Journal of Dermatology, vol. 48, no. 11, pp. 1201-1205, 2009.

[140] C. Bazzocchi, M. Mortarino, G. Grandi et al., "Combined ivermectin and doxycycline treatment has microfilaricidal and adulticidal activity against Dirofilaria immitis in experimentally infected dogs," International Journal for Parasitology, vol. 38, no. 12, pp. 1401-1410, 2008.

[141] A. Menozzi, S. Bertini, L. Turin, P. Serventi, L. Kramer, and C. Bazzocchi, "Doxycycline levels and anti-Wolbachia antibodies in sera from dogs experimentally infected with Dirofilaria immitis and treated with a combination of ivermectin/doxycycline," Veterinary Parasitology, vol. 209, no. 3-4, pp. 281-284, 2015.

[142] G. Grandi, C. Quintavalla, A. Mavropoulou et al., "A combination of doxycycline and ivermectin is adulticidal in dogs with naturally acquired heartworm disease (Dirofilaria immitis)," Veterinary Parasitology, vol. 169, no. 3-4, pp. 347-351, 2010.

[143] A. K. Sangaré, J. M. Rolain, J. Gaudart, P. Weber, and D. Raoult, "Synergistic activity of antibiotics combined with ivermectin to kill body lice," International Journal of Antimicrobial Agents, vol. 47, no. 3, pp. 217-223, 2015. 

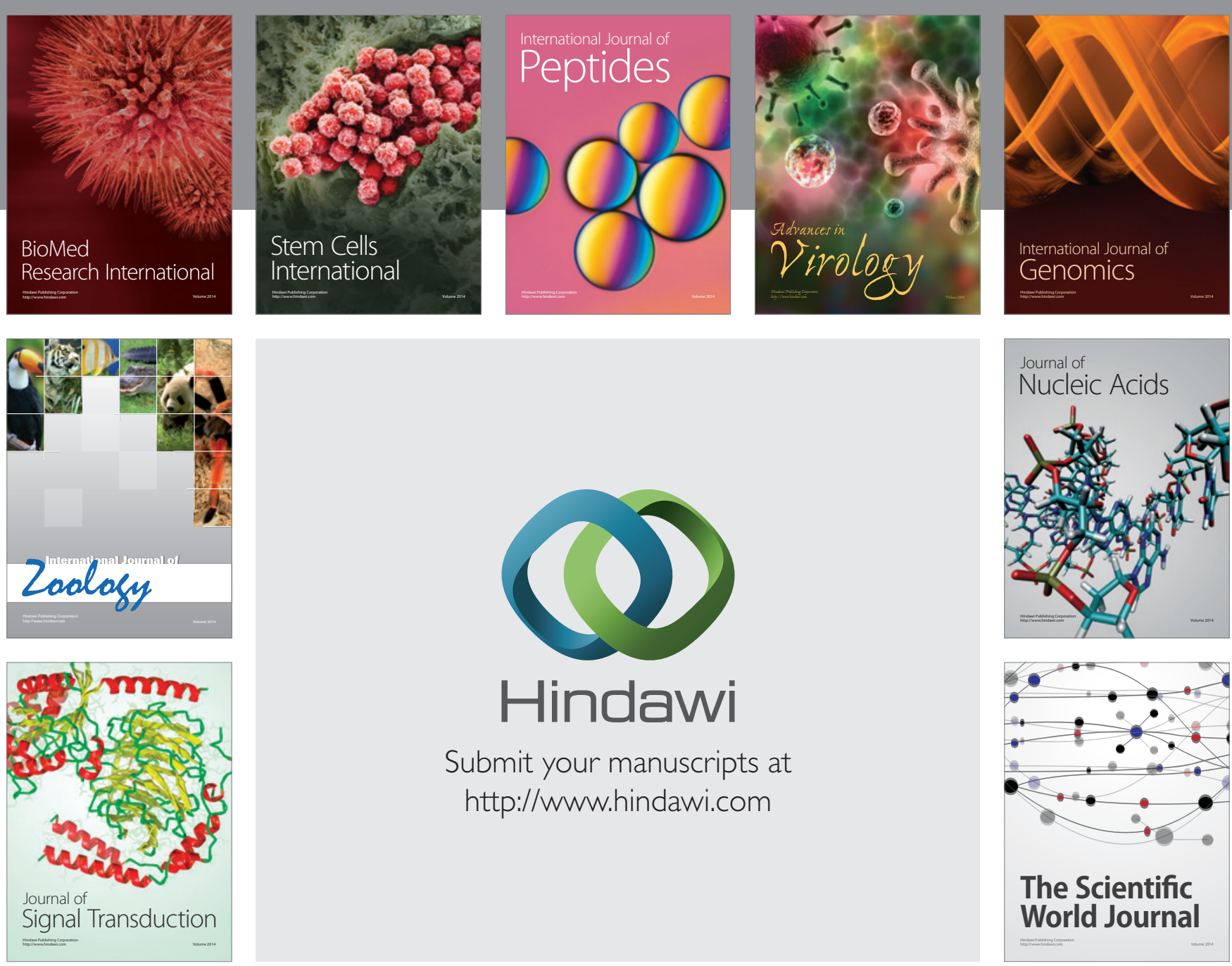

Submit your manuscripts at

http://www.hindawi.com
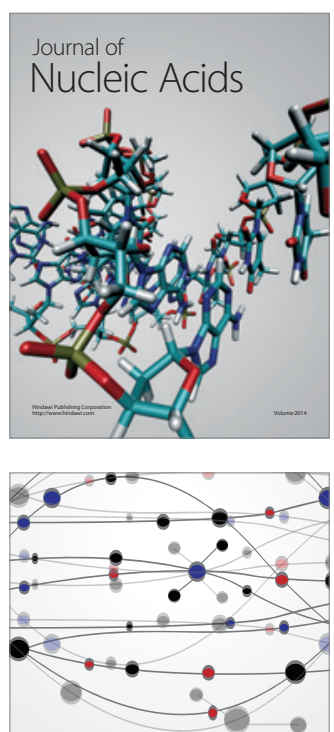

The Scientific World Journal
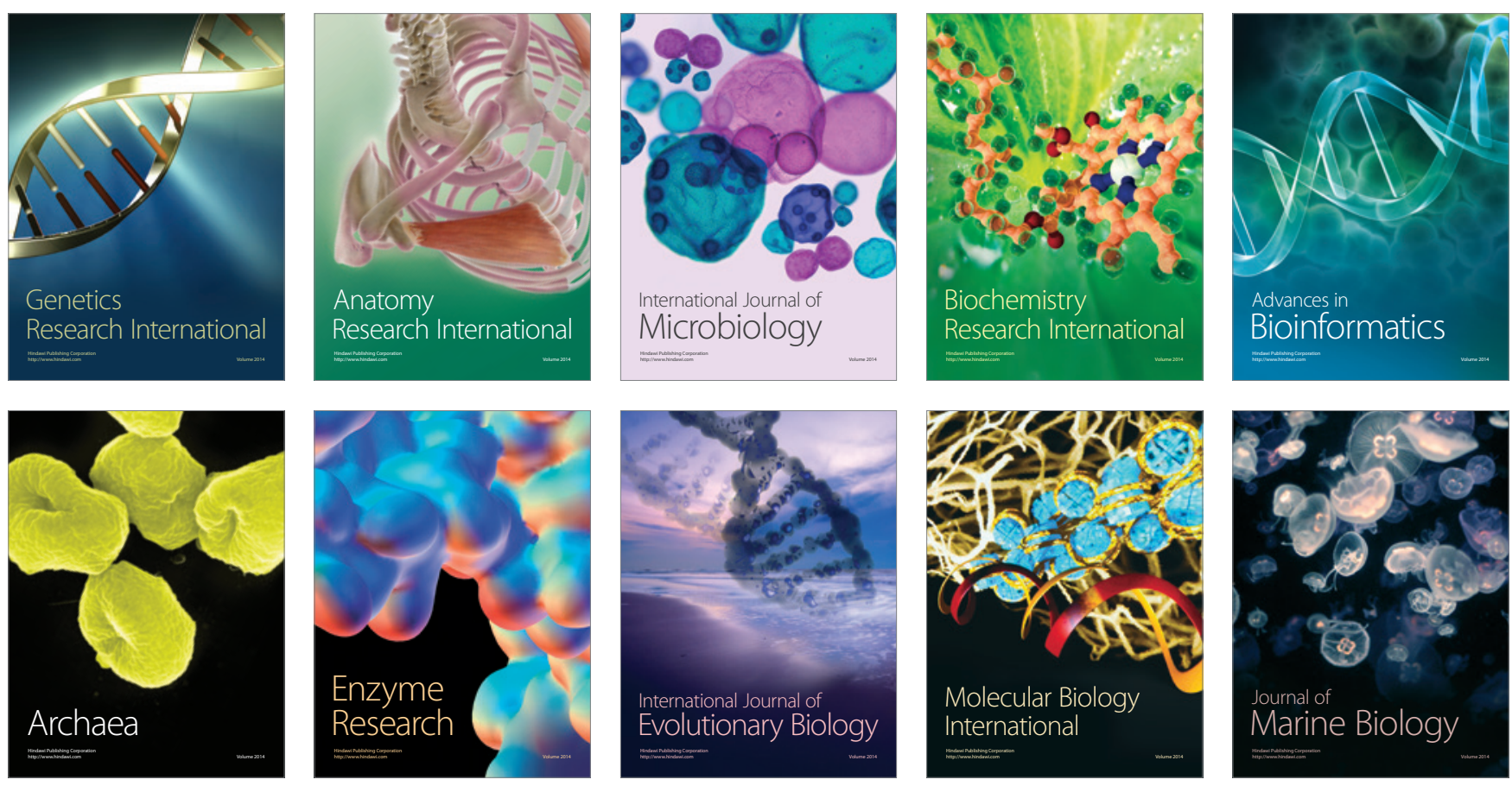